\title{
Perbandingan Sevofluran dengan Propofol Target Controlled Infusion (TCI) sebagai Rumatan Anestesi terhadap Waktu pulih Sadar dan Komplikasi Mual Muntah pada Operasi Timpanoplasti
}

\author{
Desvita Rosana, ${ }^{1}$ Dedi Fitri Yadi, ${ }^{2}$ Ricky Aditya ${ }^{2}$ \\ ${ }^{1}$ Rumah Sakit Dr. Suyoto Pusrehab Kemhan Jakarta, ${ }^{2}$ Departemen Anestesiologi dan Terapi Intensif \\ Fakultas Kedokteran Universitas Padjadjaran/RSUP Dr. Hasan Sadikin Bandung
}

\begin{abstract}
Abstrak
Praktik anestesi membutuhkan kualitas anestesi yang baik, efek samping minimal, serta pemulihan cepat. Propofol dan sevofluran memiliki efek farmakologis pemulihan pascaanestesi yang cepat. Penelitian ini bertujuan mengetahui perbandingan sevofluran dengan propofol target controlled infusion (TCI) sebagai rumatan anestesi terhadap waktu pulih sadar dan komplikasi mual muntah pada operasi timpanoplasti. Penelitian dilakukan periode Agustus-November 2018 di RSUP Dr. Hasan Sadikin Bandung. Penelitian merupakan prospektif eksperimental menggunakan uji klinis acak buta tunggal terhadap 44 subjek yang dibagi acak menjadi dua kelompok, yaitu kelompok propofol TCI (kelompok P, n=22) dan kelompok sevofluran (kelompok $\mathrm{S}, \mathrm{n}=22$ ). Selama operasi dicatat lama operasi, jumlah opioid, waktu pulih sadar, dan komplikasi mual muntah. Analisis statistik data numerik dengan uji t tidak berpasangan dan Mann Whitney, data kategorik dengan uji chi square. Hasil penelitian tidak ada perbedaan signifikan $(p>0,05)$ untuk karakteristik pasien, lama operasi, dan jumlah opioid perioperatif. Waktu pulih sadar kelompok sevofluran lebih cepat signifikan dibanding dengan propofol TCI $(10,26 \pm 1,91$ menit dan $13,36 \pm 1,72$ menit; $p<0,05)$. Komplikasi mual muntah pascaoperasi kelompok sevofluran lebih besar signifikan dibanding dengan propofol TCI $(15$ dan $1 ; p<0,05)$. Simpulan, sevofluran memiliki waktu pulih sadar lebih cepat dibanding dengan propofol TCI, namun komplikasi mual muntah sevofluran lebih besar.
\end{abstract}

Kata kunci: Komplikasi mual muntah, propofol TCI, sevofluran, timpanoplasti, waktu pulih sadar

\section{Comparison between Effect of Sevoflurane with Propofol Target Controlled Infusion (TCI) as Maintenance of Anesthesia on Emergence Time and Nausea- Vomiting Complication in Timpanoplasty Surgery}

\begin{abstract}
Current modern anesthesia practice requires good anesthetic quality, minimum side effect, and early recovery. Propofol and sevoflurane have pharmacological properties that include fast recovery after anesthesia. The aim of this study was to evaluate the comparative effects of sevoflurane versus propofol target controlled infusion (TCI) for maintenance of anesthesia with respect to emergence time and postoperative nausea and vomiting (PONV) complication in patients undergoing timpanoplasty surgery. The study was carried out from August-November 2018 in Dr. Hasan Sadikin Bandung Hospital. It was a prospective single blind experimental study conducted on 44 subjects who were randomly divided to receive either propofol TCI (group $P, n=22$ ) or sevoflurane (group $S, n=22$ ). Duration of surgery, total ammount of opioid used, emergence time, and postoperative nausea and vomiting complication were recorded. Numerical data were tested by unpaired t test and Mann Whitney while categorical data were tested by chi-square. The results showed that patient characteristics, duration of surgery, and total amount of opioid used were not significantly different ( $p>0.05$ ). Emergence time of the sevoflurane (S) group was significantly faster than the propofol (P) group $(10.26+1.91$ and $13.36+1.72$, respectively; $p<0.05)$. The complication of postoperative nausea and vomiting in group $S$ was significantly higher compared to group P ( 15 and 1 , respectively; $p<0.05)$. It is concluded that sevoflurane has faster emergence time compared to propofol TCI, but PONV complication of sevoflurane is higher.
\end{abstract}

Keywords: Emergence time, Postoperative Nausea and Vomiting, sevoflurane, TCI propofol, tympanoplasty

Korespondensi: Desvita Rosana, dr, Rumah Sakit Dr. Suyoto Pusrehab Kemhan, Jl. RC Veteran Bintaro No. 178, Bintaro, Jakarta Selatan, Tlpn (021) 7388 4000,Email desvita.rosana@gmail.com 


\section{Pendahuluan}

Praktik anestesi membutuhkan kualitas anestesi yang baik dengan efek samping minimal serta pemulihan yang cepat. Salah satu faktor yang menentukan kecepatan pemulihan anestesi umum adalah pemilihan teknik anestesi yang ideal. ${ }^{1,2}$ Sevofluran sebagai agen anestesi inhalasi dan propofol sebagai komponen total intravenous anesthesia (TIVA) mendekati kriteria agen anestesi ideal sehingga banyak digunakan pada anestesi umum. $^{1-4}$

Sevofluran mempunyai koefisien partisi volatile darah yang rendah, onset yang cepat, mudah dititrasi, serta cepat dikeluarkan dari pernapasan sehingga menjadi pilihan untuk induksi dan rumatan pada anestesi umum karena pemulihan yang singkat. ${ }^{2-5}$ Penggunaan TIVA propofol dengan metode target controlled infusion (TCI) diketahui memiliki onset kerja yang cepat, metabolisme singkat, dan memiliki efek antiemetik sehingga dapat digunakan sebagai alternatif dari anestesi inhalasi untuk rumatan anestesi umum. Berdasar atas model farmakokinetik, sistem TCI akan mentitrasi dan juga mempertahankan konsentrasi obat sesuai kebutuhan sehingga lebih tepat untuk mencapai efek. ${ }^{6,7}$

Penelitian yang membandingkan antara propofol dan sevofluran pada anestesi umum menunjukkan perbedaan signifikan pada pemulihan setelah dihentikan obat anestesi dengan buka mata spontan, menggenggam tangan lebih cepat pada grup sevofluran dibanding dengan grup propofol. ${ }^{1}$ Penelitian lain menunjukkan waktu buka mata spontan serta mampu berkomunikasi verbal lebih cepat pada grup sevofluran bila dibanding dengan grup propofol. ${ }^{2}$ Penelitian yang dilakukan pada operasi ambulatori ekstirpasi fibroadenoma payudara di RSUP Dr. Hasan Sadikin memperlihatkan waktu pulih sadar pada kelompok sevofluran yang lebih cepat dibanding dengan kelompok TIVA propofol menggunakan TCI dengan monitor kedalaman anestesi dengan Bispectral Index (BIS). ${ }^{8}$

Operasi telinga tengah termasuk bagian dari jenis operasi telinga hidung tenggorokan
(THT) yang memiliki risiko terjadi mual muntah pascaoperasi yang tinggi dengan angka kejadian mual muntah pascaoperasi sebesar 50-80\%. ${ }^{9,10}$ Risiko PONV meningkat sampai $80 \%$ pada wanita, riwayat motion sickness atau mual muntah pascaoperasi sebelumnya, obesitas, bukan perokok, serta tipe operasi. ${ }^{11}$ Penelitian sebelumnya menyatakan mual muntah pascaoperasi terjadi pada 59\% pasien yang dilakukan anestesi umum dengan inhalasi dan nitrous oksida. ${ }^{10,11}$ Kombinasi penggunaan propofol dan air menurunkan risiko mual muntah sebesar $25 \%{ }^{11}$

Penelitian yang membandingkan rumatan anestesi TIVA propofol dengan anestesi sevofluran terhadap operasi kolesistektomi, dengan hasil kejadian mual muntah lebih tinggi pada grup sevofluran, sedangkan pada grup propofol tidak ada kejadian muntah. ${ }^{12}$ Penelitian lain yang dilakukan pada operasi nefrolitotomi didapatkan waktu pulih sadar pada grup propofol lebih lama dibanding dengan grup sevofluran, dan angka kejadian mual muntah pascaoperasi pada grup sevofluran lebih besar bila dibanding dengan grup propofol. ${ }^{13}$ Penelitian yang dilakukan pada operasi payudara menunjukkan angka kejadian mual muntah pascaoperasi lebih besar pada kelompok sevofluran sebesar $50 \%$ dibanding dengan kelompok TIVA propofol $14 \%$, dengan total biaya yang dihasilkan lebih rendah pada kelompok TIVA propofol. ${ }^{4}$

Selama ini penggunaan rumatan anestesi umum pada operasi timpanoplasti di RSUP Dr. Hasan Sadikin Bandung dilaksanakan dengan anestesi inhalasi dan belum pernah mempergunakan TIVA propofol TCI. Belum ada data mengenai waktu pulih sadar dan angka komplikasi mual muntah yang terjadi pascaoperasi timpanoplasti selama di ruang pemulihan. Penggunaan TIVA propofol dengan metode TCI dapat menjadi alternatif rumatan anestesi umum pada operasi timpanoplasti di RSUP Dr. Hasan Sadikin Bandung dengan efek antiemetik yang dimiliki sehingga peneliti tertarik melakukan penelitian ini.

Tujuan penelitian ini adalah mengetahui perbandingan waktu pulih sadar dan juga komplikasi mual muntah antara penggunaan 
sevofluran dan propofol TCI sebagai rumatan anestesi pada operasi timpanoplasti. Penelitian ini merupakan modifikasi dari penelitian sebelumnya yang dilaksanakan pada operasi ambulatori payudara dengan durasi operasi yang singkat serta menggunakan monitor Bispectral Index (BIS) untuk pemantauan kedalaman anestesi di RSUP dr. Hasan Sadikin Bandung.

\section{Subjek dan Metode}

Penelitian ini dirancang secara prospektif eksperimental dengan menggunakan uji klinis acak buta tunggal. Subjek penelitian adalah pasien yang menjalani operasi timpanoplasti di RSUP Dr. Hasan Sadikin Bandung selama bulan Agustus 2018 hingga November 2018. Kriteria inklusi pada penelitian ini, yaitu usia pasien 18-65 tahun, status fisik berdasar atas American Society of Anesthesiologists (ASA) dalam kategori I-II, dan indeks massa tubuh (IMT) normal 18,50-24,99 $\left(\mathrm{kg} / \mathrm{m}^{2}\right)$. Kriteria eksklusi meliputi pasien dengan gastritis, riwayat motion sickness, riwayat mual muntah pascaoperasi, atau penggunaan antiemetik dalam 24 jam terakhir.

Penentuan besar sampel dilaksanakan berdasar atas perhitungan statistik dengan cara menetapkan taraf kepercayaan 95\%. Berdasarkan perhitungan didapatkan jumlah sampel minimal untuk tiap-tiap kelompok adalah 22 pasien sehingga total sampel minimal untuk 2 kelompok adalah 44 pasien. Pengambilan sampel penelitian dilakukan dengan teknik consecutive sampling dan subjek dialokasikan ke dalam salah satu kelompok mempergunakan blok permutasi.

Setelah mendapatkan persetujuan dari Komite Etik Penelitian Kesehatan Rumah Sakit Umum Pusat Dr. Hasan Sadikin/Fakultas Kedokteran Universitas Padjadjaran, peserta penelitian yang memenuhi kriteria inklusi dan tidak termasuk kriteria eksklusi dibagi menjadi dua kelompok, kemudian diberikan informasi kepada keluarga pasien untuk menandatangani persetujuan atau informed consent kepada pasien mengenai penelitian yang dilakukan. Sampel dibagi menjadi dua kelompok, yaitu kelompok yang mendapat rumatan anestesi sevofluran (kelompok S) dan kelompok yang mendapat rumatan anestesi propofol TCI (kelompok P).

Semua pasien sudah dipuasakan selama enam jam preoperasi dan mendapat cairan infus rumatan. Pasien dimasukkan ke dalam kamar operasi dan dilakukan pemasangan monitor. Induksi anestesi terhadap kedua kelompok dilakukan dengan preoksigenasi oksigen $100 \%$ selama 3-5 menit, kemudian diberikan fentanil $2 \mathrm{mcg} / \mathrm{kgBB}$. Pada kelompok $\mathrm{S}$ diberikan bolus intravena propofol $2 \mathrm{mg} /$ $\mathrm{kgBB}$, atrakurium $0,5 \mathrm{mg} / \mathrm{kgBB}$, dan dilakukan intubasi endotrakeal. Pada kelompok $P$ diberikan TIVA propofol metode TCI Schnider effect concentration dengan memasukkan data demografi pasien berupa usia (tahun), jenis kelamin, berat badan, dan tinggi badan. Propofol yang sudah disiapkan dalam spuit $50 \mathrm{~mL}$ dipasang ke syringe pump B Braun dan dihubungkan ke pasien menggunakan line perfusor dengan dosis TCI Schnider concentration effect $(\mathrm{Ce})$ target $4 \mathrm{mcg} / \mathrm{mL}$. Setelah pasien tertidur diberikan atrakurium $0,5 \mathrm{mg} / \mathrm{kgBB}$ dan intubasi endotrakeal. Alat syringe pump TCI akan memberikan bolus obat induksi dilanjutkan dengan rumatan anestesi secara automatis disertai pemberian $\mathrm{O}_{2}:$ Air 50\%:50\%.

Semua pasien diberikan analgetik preemptive dengan ketorolak 0,5 mg/kgBB intravena. Rumatan cairan Ringer lactat diberikan 1-2 mL/kgBB/jam. Pada kelompok $\mathrm{S}$ rumatan anestesi menggunakan sevofluran dengan pemberian $\mathrm{O}_{2}$ :Air 50\%:50\%. Kelompok $\mathrm{P}$ rumatan anestesi mempergunakan TIVA propofol metode TCI dengan concentration effect (Ce) $4 \mathrm{mcg} / \mathrm{mL}$ yang dapat dititrasi naik atau turun. Kedalaman anestesi dipantau melalui perubahan pada hemodinamik serta PRST score (dijaga tetap <3). Pemantauan hemodinamik dan PRST dilakukan setiap 5 menit. Konsentrasi propofol TCI atau sevofluran dititrasi naik atau turun berdasar atas hemodinamik yang ditandai oleh hipertensi (tekanan arteri rerata $>20 \%$ di atas baseline preoperatif), hipotensi (tekanan darah sistole $<90 \mathrm{mmHg}$ ), takikardia (frekuensi 
nadi $>20 \%$ di atas baseline preoperatif), atau bradikardia (frekuensi nadi $<50 x /$ menit). Bila terdapat hipertensi dan takikardia diatasi dengan menaikkan Ce propofol TCI 0,2 mcg/mL atau sevofluran $0,5 \%$. Jika dua kali penambahan tidak berhasil maka range Ce untuk TCI propofol ditingkatkan menjadi $0,5 \mathrm{mcg} / \mathrm{mL}$ dan sevofluran 0,5 vol\%. Jika terdapat hipotensi, pemberian $\mathrm{Ce}$ propofol TCI diturunkan 0,2 $\mathrm{mcg} / \mathrm{mL}$ atau sevofluran $0,5 \%$. Apabila dua kali penurunan tidak berhasil maka penurunan $\mathrm{Ce}$ untuk TCI propofol ditingkatkan menjadi 0,5 $\mathrm{mcg} / \mathrm{mL}$ dan sevofluran $0,5 \mathrm{vol} \%$. Bila skor PRST $>3$ maka dilakukan titrasi naik rumatan anestesi propofol TCI dan sevofluran sama seperti pada perubahan hemodinamik. Nyeri intraoperatif diatasi dengan pemberian fentanil $0,5 \mathrm{mcg} /$ $\mathrm{kgBB}$ secara intravena. Blokade neuromuskular atrakurium selama intraoperatif diberikan $1 / 3$ dosis induksi sesuai dengan kebutuhan. Reverse diberikan pada akhir operasi saat penjahitan kulit bila belum ada napas spontan

Tabel 1 Data Karakteristik Subjek Penelitian

\begin{tabular}{|c|c|c|c|}
\hline \multirow{3}{*}{ Variabel } & \multicolumn{2}{|c|}{ Kelompok } & \multirow{3}{*}{ Nilai p } \\
\hline & Propofol (P) & Sevofluran (S) & \\
\hline & $\mathrm{n}=\mathbf{2 2}$ & $\mathrm{n}=\mathbf{2 2}$ & \\
\hline Usia (tahun) & & & 0,66 \\
\hline Mean \pm Std & $32,09 \pm 9,47$ & $31,95 \pm 12,73$ & \\
\hline Range & $18-48$ & $18-58$ & \\
\hline Jenis kelamin & & & 0,76 \\
\hline Laki-laki & 10 & 9 & \\
\hline Perempuan & 12 & 13 & \\
\hline Berat badan $(\mathrm{kg})$ & & & 0,26 \\
\hline Mean \pm Std & $56,40 \pm 7,89$ & $54,00 \pm 6,02$ & \\
\hline Range & $42,00-72$ & $43,00-65$ & \\
\hline Tinggi badan (m) & & & 0,81 \\
\hline Mean \pm Std & $1,58 \pm 0,07$ & $1,59 \pm 0,06$ & \\
\hline Range & $1,46-1,74$ & $1,45-1,70$ & \\
\hline Indeks massa tubuh /IMT $\left(\mathrm{kg} / \mathrm{m}^{2}\right)$ & & & 0,08 \\
\hline Mean \pm Std & $22,25 \pm 1,65$ & $21,27 \pm 1,88$ & \\
\hline Range & $19,71-25,73$ & $18,56-24,21$ & \\
\hline Klasifikasi ASA & & & 1,00 \\
\hline ASA I & 21 & 21 & \\
\hline ASA II & 1 & 1 & \\
\hline Perokok (jumlah) & 4 & 3 & 1,00 \\
\hline Laki-laki & 4 & 3 & \\
\hline Perempuan & 0 & 0 & \\
\hline Bukan perokok (jumlah) & 18 & 19 & 0,56 \\
\hline Laki-laki & 5 & 7 & \\
\hline Perempuan & 13 & 12 & \\
\hline
\end{tabular}

Keterangan: nilai p diuji dengan uji t tidak berpasangan untuk data numerik berdistribusi normal. Data numerik distribusi tidak normal diuji dengan Mann Whitney. Data kategorik nilai p dihitung berdasar atas uji chisquare dan Exact Fisher. Nilai kemaknaan berdasar atas nilai p<0,05. Tanda* menunjukkan nilai $\mathrm{p}<0,05$ artinya signifkan atau bermakna secara statistik 
atau belum adekuat untuk menghilangkan efek residual dari obat pelumpuh otot. Saat operasi sudah selesai, ekstubasi dilakukan secara deep extubation. Setelah esktubasi rumatan anestesi sevofluran atau propofol TCI dimatikan, dilakukan suctioning hingga bersih dan diberikan oksigenasi sungkup 6 liter per menit. Jalur infus dilakukan flush agar tidak ada sisa propofol pada selang infus. Pasien kemudian diobservasi di ruang pemulihan. Waktu pulih sadar, yaitu waktu yang dihitung sejak obat rumatan anestesi sevofluran atau propofol TCI dihentikan sampai pasien respons membuka mata spontan dengan rangsang verbal pada saat dipanggil nama. Perhitungan waktu pulih sadar menggunakan stopwatch dan dilakukan oleh dokter residen anestesi. Bila terdapat nyeri pascaoperasi di ruang pemulihan maka diberikan rescue analgetik fentanil 25 mcg intravena. Komplikasi mual muntah pascaoperasi dinilai oleh petugas paramedis di ruang pemulihan. Bila terdapat komplikasi mual muntah diberikan antiemetik ondansentron $4 \mathrm{mg}$ intravena.

Data waktu pulih sadar dan angka komplikasi mual muntah selama di ruang pemulihan lalu dimasukkan ke dalam tabel. Data lama operasi (waktu sejak dilakukan insisi sampai dengan penutupan balutan luka operasi), berapa jumlah pemberian analgetik fentanil perioperatif, serta jumlah pasien yang mendapat antiemetik juga dilakukan pencatatan. Pasien dipindahkan dari ruang pemulihan setelah Aldrete score mencapai $\geq 9$. Pencatatan komplikasi mual muntah dilakukan selama tiga jam pascaoperasi sampai pasien boleh dipindahkan ke ruang perawatan.

Analisis data numerik diuji menggunakan uji $\mathrm{t}$ tidak berpasangan dengan alternatif Uji Mann Whitney. Analisis data kategorik menggunakan uji chi-square dan Exact Fisher. Derajat kepercayaan 95\% hipotesis satu arah dengan hasil signifikan bila $\mathrm{p}<0,05$.

\section{Hasil}

Hasil analisis statistik pada 44 subjek penelitian menunjukkan bahwa karakteristik subjek berdasar usia, jenis kelamin, berat badan, tinggi badan, indeks massa tubuh (IMT), klasifikasi ASA, dan kebiasaan merokok pada kelompok $\mathrm{P}$ maupun kelompok $\mathrm{S}$ tidak terdapat perbedaan bermakna secara statistik ( $p>0,05$; Tabel 1). Lama operasi dan jumlah opioid perioperatif antara kelompok $\mathrm{P}$ dan kelompok $S$ menunjukkan tidak ada perbedaan bermakna secara statistik ( $p>0,05$; Tabel 2 ).

Analisis data numerik untuk waktu pulih sadar menggunakan uji $t$ didapatkan bahwa rerata waktu pulih sadar kelompok S lebih

Tabel 2 Data Lama Operasi dan Jumlah Opioid Fentanil Perioperatif antara Kelompok Propofol dan Sevofluran

\begin{tabular}{lccc}
\hline \multirow{2}{*}{ Variabel } & \multicolumn{2}{c}{ Kelompok } & \\
\cline { 2 - 3 } & $\begin{array}{c}\text { Propofol (P) } \\
\mathbf{n = 2 2}\end{array}$ & $\begin{array}{c}\text { Sevofluran (S) } \\
\mathbf{n = 2 2}\end{array}$ & Nilai p \\
\hline Lama operasi (menit) & & & 0,28 \\
$\quad$ Mean \pm Std & $194,45 \pm 51,61$ & $175,22 \pm 56,30$ & \\
$\quad$ Range & $108-260$ & $85-260$ & \\
Jumlah opioid fentanil intraoperatif (mcg) & & & 0,39 \\
100 & 10 & 12 & \\
125 & 5 & 9 & \\
150 & 7 & 1 & \\
\hline
\end{tabular}

Keterangan: nilai p untuk data numerik menggunakan Uji Mann Whitney, sedangkan untuk data kategorik menggunakan Uji Kolmogorov Smirnov. Nilai kemaknaan berdasar atas nilai $\mathrm{p}<0,05$. Tanda* menunjukkan nilai $\mathrm{p}<0,05$ artinya signifkan atau bermakna secara statistik 
Tabel 3 Perbandingan Waktu Pulih Sadar dan Komplikasi Mual Muntah antara Kelompok Propofol dan Sevofluran

\begin{tabular}{lccc}
\hline \multirow{2}{*}{ Variabel } & \multicolumn{2}{c}{ Kelompok } & \multirow{2}{*}{ Nilai p } \\
\cline { 2 - 3 } & $\begin{array}{c}\text { Propofol (P) } \\
\mathbf{n = 2 2}\end{array}$ & $\begin{array}{c}\text { Sevofluran (S) } \\
\mathbf{n = 2 2}\end{array}$ & \\
\hline Waktu pulih sadar (menit) & & & $0,0001^{* *}$ \\
$\quad$ Mean \pm Std & $13,36 \pm 1,72$ & $10,26 \pm 1,91$ & \\
$\quad \begin{array}{l}\text { Range } \\
\text { Komplikasi mual muntah }\end{array}$ & $9,55-16$ & $7,00-14,42$ & $0,0001^{* *}$ \\
Ya & 1 & 15 & \\
Tidak & 21 & 7 & \\
\hline
\end{tabular}

Keterangan: nilai $\mathrm{p}$ untuk data numerik diuji uji t tidak berpasangan, sedangkan nilai $\mathrm{p}$ untuk data kategorik menggunakan uji chi-square. Nilai kemaknaan berdasar atas nilai $\mathrm{p}<0,05$. Tanda* menunjukkan nilai $\mathrm{p}<0,05$ artinya signifkan atau bermakna secara statistik

cepat signifikan secara statistik dibanding dengan kelompok P ( $\mathrm{p}<0,05$; Tabel 3).

Analisis data kategorik untuk komplikasi mual muntah mempergunakan uji statistik chi-square diperoleh hasil komplikasi mual muntah pada kelompok S lebih besar signifikan secara statistik dibanding dengan kelompok $\mathrm{P}$ $(\mathrm{p}<0,05$; Tabel 3).

\section{Pembahasan}

Karakteristik kedua kelompok penelitian berdasar atas kriteria usia, jenis kelamin, berat badan, tinggi badan, indeks massa tubuh, klasifikasi ASA, serta kebiasaan merokok tidak berbeda bermakna secara statistik $(p>0,05)$ sehingga kedua kelompok homogen dan layak untuk dibandingkan.

Berdasar atas skor Apfel terdapat empat faktor risiko mual muntah pascaoperasi, yaitu wanita, riwayat mengalami mual muntah pascaoperasi, bukan perokok, dan penggunaan opioid untuk analgetik pascaoperasi. Perokok menurunkan risiko kejadian mual muntah melalui efek menghambat reseptor dopaminergik (D2) yang merupakan salah satu reseptor emetogenik. Polycyclic hydrocarbons yang terdapat dalam asap rokok diketahui meningkatkan cytochrome $\mathrm{P} 450$ isoenzymes dalam liver sehingga mempercepat proses degadrasi anestesi inhalasi yang bersifat emetogenik. Perokok dapat menjadi perancu pada penelitian ini karena menurunkan risiko terjadi komplikasi mual muntah. Usia, penyakit penyerta, dan obesitas juga termasuk dalam faktor risiko komplikasi mual muntah. Usia pediatrik dapat meningkatkan komplikasi mual muntah. Usia geriatrik menyebabkan sensitivitas propofol meningkat dan efek propofol yang memanjang karena cardiac output menurun dan klirens yang lebih lama sehingga waktu pulih sadar memanjang. Obesitas mampu meningkatkan komplikasi mual muntah karena akumulasi obat anestesi yang bersifat emetogenik. Selain itu, obesitas juga dapat memperlama waktu pulih sadar dari anestesi inhalasi karena redistribusi serta menimbulkan efek paradoksal dari infus propofol kontinu. ${ }^{9,14,15}$ Faktor-faktor karakteristik tersebut dapat menjadi perancu waktupulih sadardan komplikasimualmuntah, namun pada penelitian ini karakteristik kedua kelompok adalah homogen sehingga layak untuk dibandingkan.

Hasil rerata lama operasi untuk kelompok propofol 194,45 $\pm 51,61$ menit, sedangkan kelompok sevofluran $175,22 \pm 56,30$ menit. Uji analisis statistik pada kedua kelompok menunjukkan perbedaan yang tidak bermakna secara statistik $(p>0,05)$ sehingga kedua kelompok adalah homogen dan layak untuk dibandingkan. Durasi operasi merupakan salah satu faktor risiko terjadinya mual muntah pascaoperasi. ${ }^{9}$ Setiap ada peningkatan durasi 
anestesi 30 menit maka terjadi peningkatan risiko mual muntah pascaoperasi sebesar 59\% karena akumulasi agen anestesi yang bersifat emetogenik. ${ }^{14}$

Faktor risiko lain terjadi mual muntah pada pascaoperasi adalah jumlah opioid perioperatif.9 Penggunaan opioid itu dapat menyebabkan mual muntah dengan mampu menstimulasi chemoreceptor trigger zone, memperlambat motilitas saluran cerna, dan memperpanjang waktu pengosongan lambung. Penelitian sebelumnya menunjukkan bahwa $50 \%$ pasien yang menerima opioid mengalami mual muntah pascaoperasi. ${ }^{14}$ Jumlah opioid intraoperatif terbanyak antara kelompok P dan kelompok $\mathrm{S}$ tidak berbeda signifikan secara statistik $(p>0,05)$ sehingga kedua kelompok homogen.

Penggunaan propofol pada penelitian ini menggunakan metode target controlled infusion (TCI) berdasar atas farmakokinetik dan pengukuran antropometrik seperti usia, berat badan, dan tinggi badan. TCI akan mengkalkulasi seberapa banyak obat telah terakumulasi di jaringan selama pemberian serta mengatur kecepatan infus untuk dapat mempertahankan konsentrasi di plasma dan jaringan, terutama otak. Konsentrasi propofol yang ideal untuk mendapatkan derajat anestesi yang baik $4-6 \mathrm{mcg} / \mathrm{mL}^{6,7,15}$ Penelitian ini menggunakan model farmakokinetik Schnider yang menghasilkan kedalaman anestesi yang baik pada Ce $4-6 \mathrm{mcg} / \mathrm{mL}$.

Hasil penelitian ini rerata waktu pulih sadar kelompok sevofluran adalah 10,26 $\pm 1,91$ menit, lebih cepat signifikan secara statistik dibanding dengan waktu pulih sadar kelompok propofol, yaitu $13,36 \pm 1,72$ menit $(\mathrm{p}<0,05)$. Hasil penelitian ini serupa dengan penelitian yang membandingkan profil pemulihan antara rumatan anestesi mempergunakan propofol dan sevofluran mempergunakan monitoring Bispectral Index (BIS) pada anestesi umum, dengan waktu pulih sadar pada grup propofol $(10,84 \pm 1,28$ menit) lebih lama dibanding dengan grup sevofluran $\left(5,36 \pm 1,41\right.$ menit). ${ }^{1}$ Penelitian lain menunjukkan waktu buka mata spontan pada grup sevofluran $9,3 \pm 1,8$ menit lebih cepat signifikan dibanding dengan grup propofol 13,1 $\pm 1,67$ menit, waktu respons

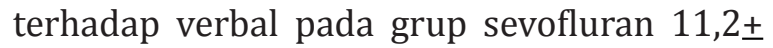
1,41 menit lebih cepat secara signifikan dari

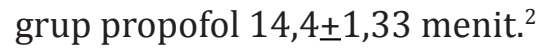

Pada penelitian yang membandingkan antara TIVA propofol dan sevofluran menggunakan monitoring bispektral indeks, didapatkan hasil penelitian waktu timbulnya napas spontan, ekstubasi, buka mata spontan pascaoperasi berturut-turut $2,4 \pm 1,5 ; 3,7 \pm 3,1$; $4,1 \pm 2,2$ pada grup sevofluran, sedangkan grup propofol berturut-turut $6,6 \pm 5,5 ; 8,0 \pm 6,5$; $9,2 \pm 7,5$ menit. ${ }^{13}$ Penelitian lain pada operasi ambulatori ekstirpasi payudara di RSUP Dr. Hasan Sadikin Bandung menunjukkan waktu pulih sadar pada kelompok sevofluran lebih cepat signifikan dibanding dengan kelompok propofol dengan monitor kedalaman anestesi menggunakan Bispectral Index (BIS). ${ }^{8}$

Pada penelitian ini waktu pulih sadar kelompok sevofluran lebih cepat dibanding dengan kelompok propofol disebabkan oleh sevofluran memiliki koefisien partisi volatil yang rendah setelah desfluran sehingga cepat mencapai equilibrium dan cepat dikeluarkan dari jaringan ke paru. Anestesi inhalasi dengan koefisien partisi darah-gas yang rendah seperti sevofluran menunjukkan penurunan konsentrasi alveolar yang lebih cepat setelah menutup vaporizer dibanding dengan isofluran dan halotan. Heksafluoroisopropanolol yang merupakan metabolit utama sevofluran berkonjugasi cepat dengan senyawa inert sehingga pemulihan singkat. ${ }^{16,17}$ Pada pasien sehat, pasca 2-3 MAC anestesi waktu bangun adalah 7,5 menit dengan mempergunakan sevofluran. ${ }^{16}$ Pada penggunaan propofol, waktu paruh distribusi inisial propofol adalah berkisar 2-4 menit dan waktu paruh eliminasi sekitar 1-3 jam. Klirens propofol dari plasma melewati aliran darah hepar. Bangun dari anestesi terjadi pada kadar propofol plasma $1-1,5 \mathrm{mcg} / \mathrm{mL}$ sehingga waktu pulih sadar propofol lebih lama bila dibanding dengan sevofluran. ${ }^{15,18}$

Penelitian ini juga memperbandingkan komplikasi mual muntah antara kelompok propofol dan sevofluran. Penelitian dilakukan pada operasi timpanoplasti yang memiliki 
risiko mual muntah pascaoperasi yang tinggi dengan angka kejadian sebesar 50-80\%. ${ }^{9,10}$ Hasil analisis penelitian ini menunjukkan jumlah subjek yang mengalami mual muntah pada kelompok propofol sebanyak satu pasien, lebih rendah signifikan bila dibanding dengan kelompok sevofluran sebanyak 15 pasien $(\mathrm{p}<0,05)$.

Hasil yang diperoleh dari penelitian ini sesuai dengan penelitian sebelumnya, yaitu penelitian pada operasi payudara dengan angka komplikasi mual muntah pascaoperasi lebih tinggi signifikan pada grup sevofluran sebesar $50 \%$ bila dibanding dengan grup propofol sebesar $14,3 \%{ }^{4}$ Penelitian lain yang membandingkan komplikasi mual muntah pascaoperasi pada operasi kolesistektomi menunjukkan perbedaan signifikan dengan angka kejadian mual sebanyak 11 pada grup sevofluran, dan tiga pada grup propofol. Angka kejadian muntah sebesar sembilan pada grup sevofluran, sedangkan grup propofol tidak ada yang mengalami muntah. ${ }^{12}$ Apfel dan kawan-kawan mendemonstrasikan bahwa mual muntah pascaoperasi terjadi pada $59 \%$ pasien yang menggunakan anestesi inhalasi dan nitrous oksida.

Patofisiologi terjadi muntah merupakan proses kompleks dan terbukti melibatkan beberapa organ. Pusat muntah terletak di medula oblongata dan berada dekat traktus solitarius setinggi nukleus motor dorsal dari nervus vagus. Aferen yang berasal dari traktus gastrointestinal (terutama serotoninergik), faring, mediastinum, pusat penglihatan, vestibular dari nervus delapan (terutama histaminergik), dan dari chemoreceptor trigger zone (CTZ) dekat area postrema (dopaminergik) dapat menstimulasi pusat muntah. Impuls motorik akan ditransmisi dari pusat muntah melalui nervus kranialis ke traktus gastrointestinal dan nervus spinalis menuju diagframa dan otot abdomen sehingga terjadi muntah. Propofol diketahui memiliki efek antiemetik yang meminimalkan efek sekuele muntah pascaanestesi umum.. Efek antiemetik propofol, yaitu melalui aktivitas antidopaminergik, efek depresan pada CTZ dan nukleus vagal, menurunkan pelepasan glutamat dan aspartat di korteks olfaktorius, serta pengurangan konsentrasi serotonin di area postrema. ${ }^{15,19}$ Penggunaan propofol dinyatakan menurunkan risiko mual muntah pascaoperasi sebesar 19\%. Kombinasi pada penggunaan propofol dan air menurunkan risiko mual muntah pascaoperasi sebesar 25\%. ${ }^{11,19}$ Agen anestesi inhalasi (contohnya sevofluran dan isofluran) mempunyai potensi untuk menimbulkan komplikasi berupa mual muntah dan durasi penggunaan anestesi inhalasi juga makin meningkatkan komplikasi mual muntah terutama pada saat dua jam pertama pascaoperasi di ruang pemulihan. Penggunaan sevofluran dapat memperkuat sinyal serotonin tipe $3\left(5-\mathrm{HT}_{3}\right)$ di perifer dan sentral untuk menghasilkan mual atau muntah. Selain itu, anestesi inhalasi (halotan, isofluran, sevofluran) menstimulasi serat aferen vagal, memengaruhi sistem vestibular, dan juga mengganggu fungsi gastrointestinal (gastric dysrhythmias) sehingga mencetuskan komplikasi mual muntah. ${ }^{20}$

Keterbatasan pada penelitian ini adalah pemantauan kedalaman anestesi dengan menggunakan pemantauan hemodinamik dan PRST yang kurang tepat jikalau dibanding dengan monitor Bispectral Index (BIS) untuk menilai kedalaman anestesi yang adekuat. Bila intraoperatif terjadi perubahan hemodinamik maka dilakukan titrasi naik atau turun obat rumatan anestesi.

\section{Simpulan}

Simpulan penelitian ini adalah penggunaan rumatan anestesi sevofluran pada operasi timpanoplasti memiliki waktu pulih sadar yang lebih singkat, namun dengan komplikasi mual muntah yang lebih besar jika dibanding dengan rumatan propofol TCI.

\section{Daftar Pustaka}

1. Somvanshi M, Agarwal D, Tripathi A. Comparison of recovery profiles of propofol and sevoflurane anesthesia with bispectral index monitoring (BIS) in general anesthesia. Nat J Med Res. 
2015;5(1):52-6.

2. Rasool S, Mehta N. Comparison of intraoperative haemodynamic parameters and cost effectiveness between sevoflurane (inhalational) anesthesia and propofol (TIVA) based anesthesia. IOSR J Dental Med Sci. 2017;16(8):73-7.

3. Kocaturk 0. Postoperative complications in total intravenous anesthesia with propofol compare with sevoflurane anesthesia: a retrospective study. Med Sci. 2018;7(2):290-4.

4. Chen HP, Hsu YH, Hua KC, Lin CC, Lo YF, Yu HP. Comparison of sevoflurane versus propofol under auditory evoked potential monitoring in female patients undergoing breast surgery Biomed J. 2013;36:125-31.

5. Kriti C, Indu V, Vyas C, Nischitha G. Comparative study of effect of sevoflurane versus propofol based anesthesia on intraoperative maintanance of hemodynamics and recovery charateristics in patients undergoing modified radical mastectomy. Intern J Sci Study. 2016;4(3):92-6.

6. Struys MMRF, Smet TD, Glen JB, Vereecke HEM, Absalom AR, Schnider TW. The history of target controlled infusion. Anesth Clin Pharmacol. 2016;122:56-69.

7. Egan TD. Target controlled drug delivery: Progress toward an intravenous "vaporizer" and automated anesthetic administration. American Society of Anesthesiologist Inc Lippincott Williams \& Wilkins. 2003;99:1214-8.

8. Arvianto, Oktaliansah E, Surahman E. Perbandingan antara sevofluran dan propofol menggunakan total intravenous anesthesia target controlled infusion terhadap waktu pulih sadar dan pemulangan pasien pada ekstirpasi fibroadenoma payudara. JAP. 2017;5(1):24-31.

9. Sweis I, Yegiyant SS, Cohen MN. The management of postoperative nausea and vomiting: current thoughts and protocols. Aesthetic Plast Surg. 2013;37(3):625-33.

10. Lee DW, Lee HG, Jeong CY, Jeong SW, Lee $\mathrm{SH}$. Postoperative nausea and vomiting after mastodectomy with tympanoplasty: a comparison between TIVA with propofolremifentanil and balanced anesthesia with sevoflurane-remifentanil. Korean J Anesthesiol. 2011;61(5):399-404.

11. Smith HS, Smith EJ, Smith BR. Postoperative nausea and vomiting. Ann Palliat Med. 2012;1(2):94-102.

12. Singh SK, Kumar A, Mahajan R, Katyal S, Mann S. Comparison of recovery profile for propofol and sevoflurane anesthesia in cases of open cholecystectomy. Anesth Essays Res. 2013;7(3):386-9.

13. Orhon ZN, Devrim S, Celik M, Dogan Y, Yildrim A, Basok EK. Comparison of recovery profiles on propofol and sevoflurane anesthesia with bispectral index monitoring in percutanous nephrolitotomy. Korean J Anesthesiol. 2013;64(3):223-8.

14. Apipan B, Rummasak D, Wongsirichat N. Postoperative nausea and vomiting after general anesthesia for oral and maxillifacial surgery. J Dent Anest Pain Med. 2016;16(4):273-81.

15. Butterworth JF, Mackey DC, Wasnick JD, penyunting. Intravenous anesthetics. Morgan \& Mikhail's clinical anesthesiology. Edisi ke-6. New York: Mc Graw Hill Education; 2018.

16. Preckel B, Bolten J. Pharmacology of modern volatile anesthesics. Best Practice Res Clin Anaesthesiol. 2005;19:331-48.

17. Butterworth JF, Mackey DC, Wasnick JD, penyunting. Inhalation anesthetics. Morgan \& Mikhail's clinical anesthesiology. Edisi ke-6. New York: Mc Graw Hill Education; 2018.

18. Abola R, Geralemou S, Szafran M, Gan TJ. Intravenous anesthesia. Dalam: Barash PG, Cullen BF, Stoelting RK, Cahalan MK, Stock MC, Ortega R, penyunting. Clinical anesthesia. Edisi ke-8. Philadelphia: Lipincott Wiliams and Wilkins; 2017. hlm. 1252-67.

19. Apfel CC, Stoecklein K, Lipfert P. PONV: a problem of inhalational anesthesia? Best Practice Res Clin Anaesthesiol. 2005;19:485-500. 
20. Horn CC, Wallisch WJ, Homanics GE, Williams JP. Pathophysiological and neurochemical mechanism of postoperative nausea and vomiting. Eur J Pharmacol. 2015;722:1-27. 